Article

\title{
Porous Alumosilicate Aggregate as Lead Ion Sorbent in Wastewater Treatments
}

\author{
Andrea Petrella 1,* (D), Pinalysa Cosma ${ }^{2}$ (D), Vito Rizzi ${ }^{2}$ (D) and Nicoletta De Vietro ${ }^{2}$ \\ 1 Dipartimento di Ingegneria Civile, Ambientale, Edile, del Territorio e di Chimica, Politecnico di Bari, \\ Orabona, 4, 70125 Bari, Italy \\ 2 Dipartimento di Chimica, Università degli Studi di Bari “Aldo Moro”, Orabona, 4, 70125 Bari, Italy; \\ pinalysa.cosma@uniba.it (P.C.); vito.rizzi@uniba.it (V.R.); nicoletta.devietro@uniba.it (N.D.V.) \\ * Correspondence: andrea.petrella@poliba.it; Tel.: +39(0)-805-963-275
}

Received: 20 April 2017; Accepted: 27 July 2017; Published: 3 August 2017

\begin{abstract}
Porous alumosilicate aggregate, namely perlite, was used as an alternative material in wastewater treatments for the selective removal of ionic pollutants such as lead which is present in industrial wastewaters and toxic at relatively low concentrations. Metal retention was investigated by single metals and multispecies equilibrium isotherms (batch system) and by carrying out dynamic (column) experiments. Lead ions were supposedly preferentially retained by ion exchange at the negatively charged silicate functional groups present on the perlite material, and to a minor extent by weak electrostatic (Van der Waals) interactions at non-specific functionalities. In the case of the batch system, the Freundlich isotherm gave a good correlation of the experimental data and lead maximum retention $\left(q_{\max }\right)$ in single ion solution was $4.28 \mathrm{mg} / \mathrm{g}_{\text {perlite, }}$ and in multimetal solution was $1.50 \mathrm{mg} / \mathrm{g}_{\text {perlite. }}$. In the case of the column system, overall capacity was $3.7 \mathrm{mg} / \mathrm{g}_{\text {perlite }}$ in single ion solution, and in multimetal solution was $3.0 \mathrm{mg} / \mathrm{g}_{\text {perlite. }}$. In multimetal solutions, lead ions showed the best interaction at the perlite functional groups because of the lowest free energies of hydration and hydrated radius. After sorption, perlite beads were used as lightweight aggregates for cement mortars after evaluation of the potential release of lead ions from the conglomerates.
\end{abstract}

Keywords: perlite; lead ion retention; ion exchange; Freundlich isotherm; metal-laden material; lightweight mortars

\section{Introduction}

Perlite is a volcanic rock with high water content, low density and expanding property after heating. Specifically, the temperature at which expansion takes place ranges from 760 to $1100{ }^{\circ} \mathrm{C}$ with a 10-20-fold volume increase due to water evaporation [1]. Due to its lightness, perlite may be effectively used in the construction industry as an aggregate for lightweight conglomerates such as concrete and mortars.

The novelty of the present paper is to evaluate the potentialities of perlite beads in environmental applications as lead ion sorbent from industrial wastewaters with a following re-use in the construction industry.

Lead is present in industrial wastewaters and considered extremely dangerous even at relatively low concentrations [2-4]. Lead has many different agricultural, domestic and industrial applications; for this reason, effluents from the production of, e.g., batteries, metal products together with chemical industries need to be treated before discharge into recipient water bodies [5-9].

In the present work, the sorption properties of perlite toward lead ions present in metal solutions were evaluated after batch and column tests. The Langmuir and Freundlich isotherms were used to model batch sorption data $[10,11]$. After metal retention, exhausted perlite can be re-used as a thermal insulator in cement mortars [12-14] thus minimizing potential environmental impact associated with 
the release of the pollutants. Specifically, the reference conglomerates were characterized both in thermal and mechanical tests.

\section{Materials and Methods}

\subsection{Materials Characterization and Sorption Experiments}

Perlite $\left(\mathrm{SiO}_{2} 74 \%-78 \%, \mathrm{Al}_{2} \mathrm{O}_{3} 11 \%-14 \%, \mathrm{~K}_{2} \mathrm{O} 2 \%-4 \%, \mathrm{Na}_{2} \mathrm{O} 3 \%-6 \%, \mathrm{Fe}_{2} \mathrm{O}_{3} \quad 0.5 \%-1.5 \%\right.$, $\mathrm{CaO} 1 \%-2 \%, \mathrm{MgO}$ 0\%-0.5\%) was supplied by Maltek Industrie S.r.l., Terlizzi, Bari, Italy. Scanning Electron Microscope (SEM) analysis was carried out by an electron microscope FESEM-EDX Carl Zeiss Sigma 300 VP (Carl Zeiss Microscopy GmbH, Jena, Germany). The sample was fixed on aluminum stubs (circular, $1 \mathrm{~cm}$ diameter) and then sputtered with graphite by the use of a Sputter Quorum Q150 (Quorum Technologies Ltd., East Sussex, UK). Pictures were acquired by SmartSEM Zeiss software (Carl Zeiss Microscopy GmbH, Jena, Germany).

BET surface area and pore size of the sorbent were determined by adsorption-desorption $\mathrm{N}_{2}$ isotherms at $77 \mathrm{~K}$, by an Autosorb IQ Chemi TCD instrument (Quantachrome Instruments, Boynton Beach, FL, USA). The biosorbent was apparently a mesoporous material with pore diameters ranging 20-500 $\AA$, average pore radius $16.535 \AA$ and BET total surface area exceeding $1.664 \mathrm{~m}^{2} / \mathrm{g}$. Referring to the pores, the total volume and surface area were respectively $0.008 \mathrm{~cm}^{3} / \mathrm{g}$ and $1.010 \mathrm{~m}^{2} / \mathrm{g}$.

Sorption experiments were carried out by the use of metal solutions starting from reactive grade $\mathrm{Pb}\left(\mathrm{NO}_{3}\right)_{2}, \mathrm{Cd}\left(\mathrm{NO}_{3}\right)_{2} \cdot 4 \mathrm{H}_{2} \mathrm{O}, \mathrm{Ni}\left(\mathrm{NO}_{3}\right)_{2} \cdot 7 \mathrm{H}_{2} \mathrm{O}$ from Carlo Erba, Milan, Italy.

A first set of batch equilibrium experiments was carried-out by contacting $200 \mathrm{~cm}^{3}$ of single metal containing solution $\left(15 \mathrm{mg}\left(\mathrm{Pb}^{+2}\right) / \mathrm{dm}^{3}\right.$ in de-mineralized water, $\left.\mathrm{pH}=6\right)$ with $20-1200 \mathrm{mg}$ of 1-2 mm sorbent. A second set of experiments was carried out by contacting $200 \mathrm{~cm}^{3}$ of ternary metal $\left(\mathrm{Pb}^{+2}, \mathrm{Cd}^{+2}, \mathrm{Ni}^{+2}\right)$ containing solution $\left(15 \mathrm{mg}\left(\mathrm{Me}^{+2}\right) / \mathrm{dm}^{3}\right.$ each in de-mineralized water, $\left.\mathrm{pH}=6\right)$ with $30-8000 \mathrm{mg}$ of $1-2 \mathrm{~mm}$ sorbent. The vials were stirred at $80 \mathrm{rpm}$ and room temperature till equilibration of the solution concentration ( $<5 \%$ of two subsequent samplings).

Dynamic (column) experiments were carried out with single and ternary metal solutions in de-mineralized water $\left(15 \mathrm{mg}\left(\mathrm{Me}^{+2}\right) / \mathrm{dm}^{3}\right.$ each, $\mathrm{pH}=6$ ). Specifically, columns (I.D. $=1.0 \mathrm{~cm} ; \mathrm{H}=50 \mathrm{~cm}$ ) were loaded with $4 \mathrm{~g}$ of 1-2 $\mathrm{mm}$ sorbent and the flow rate exceeded $0.3 \mathrm{~L} / \mathrm{h}$. Experiments were extended to the complete exhaustion of the perlite bed (i.e., effluent $\mathrm{Me}^{+2}$ concentration equal to the influent).

Liquid-phase metal concentrations were determined by Flame Atomic Absorption Spectrometry using a Mod.929 Spectrometer from Unicam, Milan, Italy.

\subsection{Sorption Models for Batch Tests}

Langmuir and Freundlich models $[10,11]$ were chosen to correlate batch sorption data.

The Langmuir model is conventionally applied for a monolayer sorption onto a surface showing equivalent sites. After linearization, the Langmuir equation may be expressed as:

$$
C_{e q} / q_{e q}=1 / b q_{\max }+C_{e q} / q_{\max }
$$

$q_{e q}$ and $q_{\max }$ are respectively the equilibrium and maximum retention capacities of the sorbent $\left(\mathrm{mg} / \mathrm{g}_{\text {perlite }}\right) ; C_{e q}$ is the equilibrium liquid-phase concentration $\left(\mathrm{mg} / \mathrm{dm}^{3}\right) ; b$ is an equilibrium constant.

The Freundlich model is conventionally applied for heterogenous surface sorption. After linearization, the Freundlich equation may be expressed as:

$$
\ln q_{e q}=1 / n \ln C_{e q}+\ln K_{f}
$$

$K_{f}$ is a constant related to the sorption capacity, $n$ is related to the sorption energy.

In case of ion exchange, the overall free energy of the ions at the sorbent active groups includes two main terms, (a) the coulombic interaction of the ions at the sorbent functional groups $\left(\Delta G_{e l}\right)$ 
and (b) the free energy of hydration/dehydration of the exchanging ions at the sorbent functional groups $\left(\Delta G_{h y d r}\right)$ :

$$
\Delta G_{\text {overall }}=\Delta G_{e l}+\Delta G_{\text {hydr }}
$$

\subsection{Column (Dinamic) Test}

A deeper insight into the interactions of the metals at the liquid-solid interface was obtained by breakthrough curves which represent time variation of the metal concentrations $\left(\mathrm{mg} / \mathrm{dm}^{3}\right)$ after elution in a packed-bed column or the effluent liquid volumes at constant flow-rate (Bed Volumes, $\left.V / V_{0}=\mathrm{BV}\right)$. Laboratory columns were loaded with perlite which was eluted with $\mathrm{Pb}^{+2}, \mathrm{Cd}^{+2}$ and $\mathrm{Ni}^{+2}$ synthetic solutions. The breakpoint corresponds to the minimum retention capacity towards metals, i.e., when the liquid-phase solution starts to be leached by the column. Complete exhaustion of the sorbent corresponds to equal concentrations of the effluent and influent solutions from the column.

\subsection{End Disposal of Metal-Laden Perlite}

After exhaustion, heavy metal-laden perlite was embedded into cement mortars which were prepared by the use of class II CEM A-LL, 42.5R cement from Buzzi Unicem, Barletta, Italy, according to standard protocols [15]. A perlite volume exceeding $500 \mathrm{~cm}^{3}$ was added.

Cube specimens $(4 \times 4 \times 4 \mathrm{~cm})$ were prepared and submitted to a jar test (Vittadini, Aqua, Milan, Italy) in order to evaluate potential release of heavy metals [16].

Thermal measurements were carried out on mortar cylinders ( $\phi=100 \mathrm{~mm} ; H=50 \mathrm{~mm}$ ) by the use of a Mod. ISOMET 2104 system from Applied Precision Ltd. (Bratislava, Slovakia). After evaluation of the temperature excursions along time and directions, thermal diffusivity data were collected and thermal conductivity was determined as an indirect parameter [17].

Mechanical tests (flexural strength) were carried out on $40 \times 40 \times 160 \mathrm{~mm}$ mortar prisms and compression tests were carried-out on the samples deriving from the mechanical flexural procedures [18].

\section{Results}

Figure 1 shows SEM micrographs of a representative perlite bead (Figure 1a) and a magnification of the open porosity (Figure 1b), together with an extended internal (closed) porosity (inset Figure 1a).

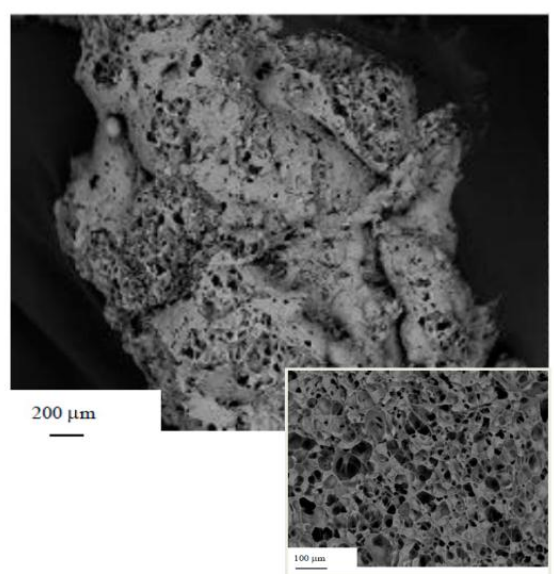

(a)

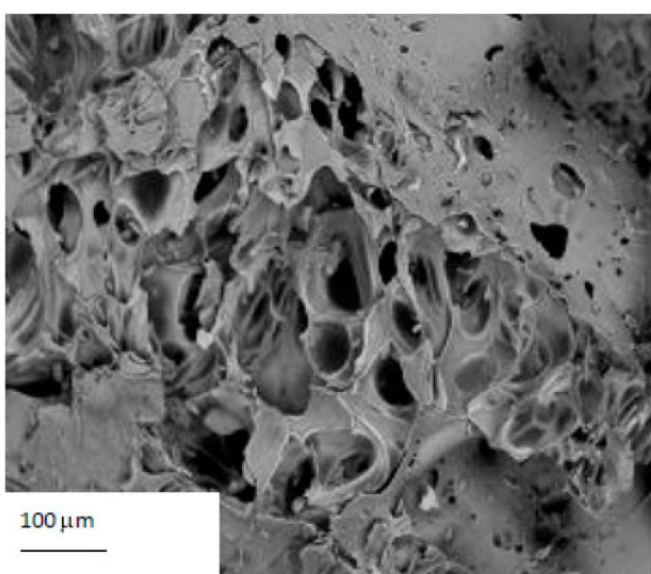

(b)

Figure 1. (a) SEM of a single perlite bead; inset: internal texture; (b) perlite external bead texture.

Table 1 summarizes the complex of the batch laboratory tests, together with the experimental maximum retention capacities. 
Table 1. Summary of the batch tests carried out on the perlite sorbent and experimental retention capacities.

\begin{tabular}{cccccc}
\hline Metal Specie & Solution & Bead Size $(\mathbf{m m})$ & $\boldsymbol{V}_{\text {sol }} \mathbf{( L )}$ & $\begin{array}{c}\text { Influent Concentration } \\
\left(\mathbf{m g}\left(\mathbf{M e}^{+2}\right) / \mathbf{d m}^{\mathbf{3}}\right)\end{array}$ & $\begin{array}{c}\text { Experimental } \boldsymbol{q}_{\text {max }} \\
\left(\mathbf{m g}\left(\mathbf{M e} \mathbf{m}^{+2}\right) / \mathbf{g}_{\mathbf{p e r l i t e}}\right)\end{array}$ \\
\hline $\mathrm{Pb}^{+2}$ & single & $1-2$ & 0.2 & 15 & $4.28 \pm 0.21$ \\
$\mathrm{Cd}^{+2}$ & ternary & $1-2$ & 0.2 & 15 & $1.5 \pm 0.07$ \\
$\mathrm{Cd}^{+2}$ & ternary & $1-2$ & 0.2 & 15 & $0.41 \pm 0.02$ \\
$\mathrm{Ni}^{+2}$ & ternary & $1-2$ & 0.2 & 15 & $0.36 \pm 0.02$ \\
\hline
\end{tabular}

Figure 2a shows the batch equilibrium curve for the experiment carried out at constant lead concentration $\left(15 \mathrm{mg} / \mathrm{dm}^{3}\right)$, bead size range $(1-2 \mathrm{~mm})$, temperature $\left(25^{\circ} \mathrm{C}\right)$ and stirring speed $(80 \mathrm{rpm})$.

Figure $2 \mathrm{~b}$ shows the effect of perlite dosage $(\mathrm{mg})$ on the sorption. Table 2 shows the relevant Freundlich and Langmuir parameters.

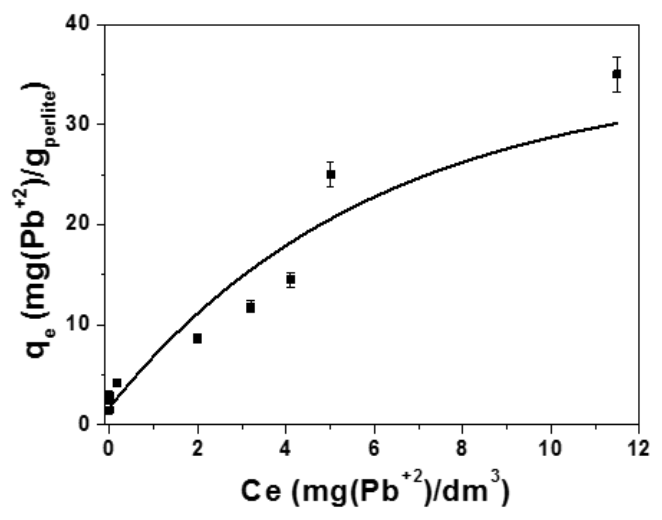

(a)

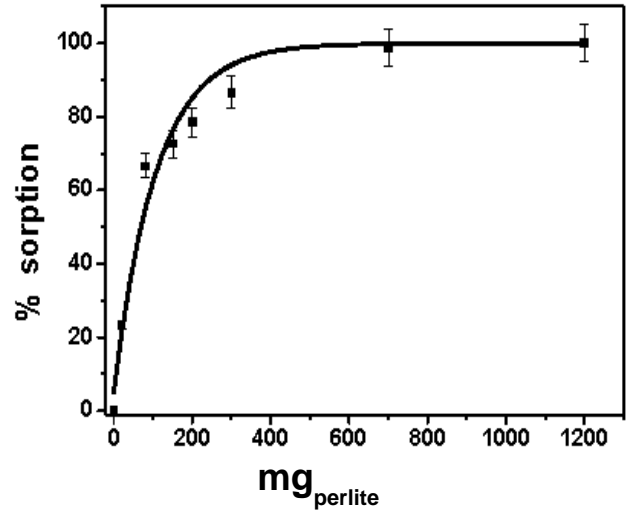

(b)

Figure 2. (a) Single batch test in de-mineralized water for lead ion retention on perlite (1-2 mm bead size, $\left.80 \mathrm{rpm}, 15 \mathrm{mg}\left(\mathrm{Pb}^{+2}\right) / \mathrm{dm}^{3}, 298 \mathrm{~K}\right)$; (b) effect of perlite dosage on the sorption.

Table 2. Freundlich $\left(K_{f}, 1 / n\right)$ and Langmuir parameters $\left(q_{\max }, b\right)$ for lead ion retention in single and ternary solution batch tests.

\begin{tabular}{ccccccc}
\hline \multirow{2}{*}{$\mathbf{P b}^{+\mathbf{2}}$} & \multicolumn{3}{c}{ Freundlich Parameters } & \multicolumn{3}{c}{ Langmuir Parameters } \\
\cline { 2 - 7 } & $\boldsymbol{K}_{\boldsymbol{f}}$ & $\mathbf{1} / \boldsymbol{n}$ & $\mathbf{R}^{\mathbf{2}}$ & $\boldsymbol{q}_{\text {max }}$ & $\boldsymbol{b}$ & $\boldsymbol{R}^{\mathbf{2}}$ \\
\hline single & 8.24 & 0.50 & 0.95 & 34.48 & 0.44 & 0.81 \\
\hline ternary & 2.86 & 0.63 & 0.97 & 27.02 & 0.105 & 0.78 \\
\hline
\end{tabular}

From a general overview of data, lead ions may be retained preferentially by strong Coulomb interactions, i.e., by ion exchange at the negatively charged silicate functional groups present on the perlite surface as a result of the following equilibrium [19]:

$$
\text { Perlite- }\left(\mathrm{Na}^{+}\right)_{n}+\mathrm{Me} e^{n+} \rightarrow \text { Perlite- } \mathrm{Me} e^{n+}+n\left(\mathrm{Na}^{+}\right)
$$

Specifically, approximately $70 \%$ of the expected release of sodium ions was experimentally detected. To a minor extent, lead ions may be retained by weak electrostatic (Van der Waals) interactions at non-specific functionalities [19] of the sorbent as observed by a better correlation of data according to the Freundlich model (Table 2). As expected, metals removal increases at higher sorbent dosages, whereas maximum sorbed quantities $\left(\mathrm{mg}\left(\mathrm{Me}^{+2}\right) / \mathrm{g}_{\text {perlite }}\right)$ decrease [20-22]. Maximum lead ion retention capacity was experimentally determined in the range $4.3 \mathrm{mg} / \mathrm{g}_{\text {perlite }}$ (Table 1 ). 
In ternary solutions, lead ions showed the best retention capacities (Figure 3a,b) [23] although lower than single ion solution (Table 1).

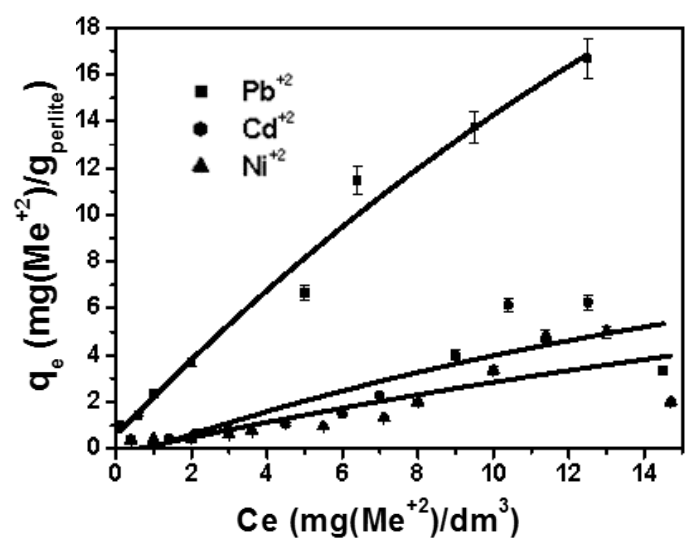

(a)

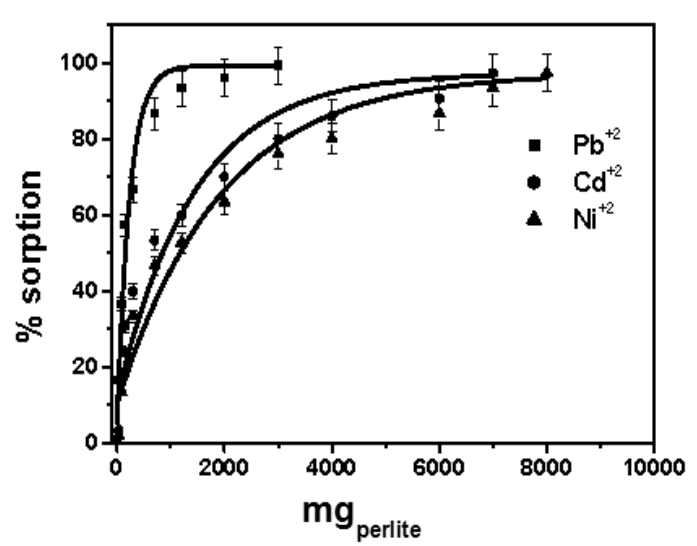

(b)

Figure 3. (a) Batch tests in de-mineralized water for a solution of lead, cadmium and nickel ions on perlite (1-2 mm bead size, $\left.80 \mathrm{rpm}, 15 \mathrm{mg}\left(\mathrm{Me}^{+2}\right) / \mathrm{dm}^{3}, 298 \mathrm{~K}\right)$; (b) effect of perlite dosage on the sorption.

Moreover, multispecies equilibria confirmed that ion exchange may be the predominant mechanism for metal retention at the sorbent functionalities (approximately $70 \%$ of sodium ions release). Maximum retention capacities were experimentally determined in the range $1.50 \mathrm{mg} / \mathrm{g}_{\text {perlite }}$, $0.41 \mathrm{mg} / \mathrm{g}_{\text {perlite}}, 0.36 \mathrm{mg} / \mathrm{g}_{\text {perlite, }}$, respectively for $\mathrm{Pb}^{+2}, \mathrm{Cd}^{+2}$ and $\mathrm{Ni}^{+2}$ (Table 1).

Dynamic tests were carried out in stationary conditions by the elution of single and ternary metal solutions ( $15 \mathrm{mg}\left(\mathrm{Me}^{+2}\right) / \mathrm{dm}^{3}$ each in demi-water) at constant flow-rate in the column exceeding $0.3 \mathrm{~L} / \mathrm{h}$. Table 3 summarizes the complex of laboratory tests carried out and Figure 4 shows the relative breakthrough curves (Figure 4).

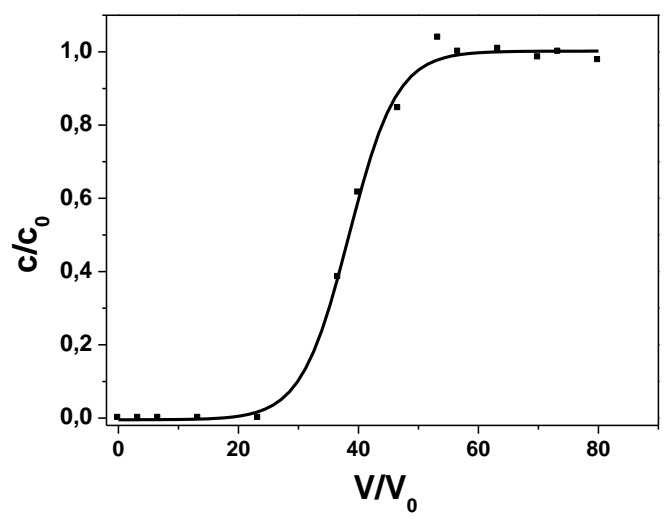

(a)

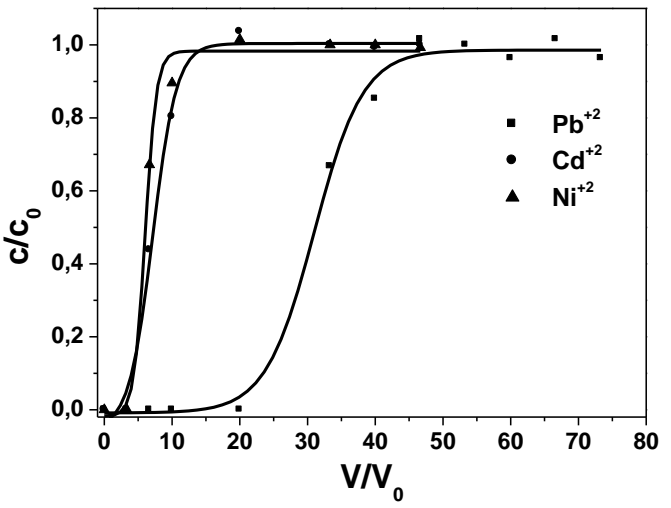

(b)

Figure 4. Breakthrough curves in de-mineralized water for (a) lead ions and (b) solution of lead, cadmium and nickel ions on perlite (1-2 mm particle size, $\left.0.3 \mathrm{~L} / \mathrm{h}, 15 \mathrm{mg}\left(\mathrm{Me}^{+2}\right) / \mathrm{dm}^{3}, \mathrm{pH}=6, \mathrm{~T}=298 \mathrm{~K}\right)$.

Relevant data at metal breakthrough are shown in Table 3. The operating capacity at complete column breakthrough for lead ions in the single metal test exceeded $3.7 \mathrm{mg}\left(\mathrm{Pb}^{+2}\right) / \mathrm{g}_{\text {perlite, }}$, whereas in ternary metal solution lead ion overall retention exceeded $3.0 \mathrm{mg}\left(\mathrm{Pb}^{+2}\right) / \mathrm{g}_{\text {perlite }}$ with an anticipated breakpoint. In the latter case, lead ions were preferentially sorbed by perlite and the operating capacities at complete column breakthrough were $3.0 \mathrm{mg}\left(\mathrm{Pb}^{+2}\right) / \mathrm{g}_{\text {perlite, }}, 0.8 \mathrm{mg}\left(\mathrm{Cd}^{+2}\right) / \mathrm{g}_{\text {perlite, }}$, and $0.6 \mathrm{mg}\left(\mathrm{Ni}^{+2}\right) / \mathrm{g}_{\text {perlite }}$ respectively (Table 3 ). 
Table 3. Summary of the column tests carried out on perlite and operative breakthrough parameters $\left(15 \mathrm{mg}\left(\mathrm{Me}^{+2}\right) / \mathrm{dm}^{3}\right.$ influent concentration, $3.8 \mathrm{~g}$ perlite $(1-2 \mathrm{~mm}), \mathrm{Vcol}=30 \mathrm{~cm}^{3}, 0.3 \mathrm{~L} / \mathrm{h}$ flow-rate).

\begin{tabular}{cccc}
\hline Metal Specie & Solution & $Q_{\text {exp }}\left(\mathbf{m g} / \mathbf{g}_{\text {perlite }}\right)$ & BV \\
\hline $\mathrm{Pb}^{+2}$ & single & $3.7 \pm 0.2$ & 33 \\
$\mathrm{~Pb}^{+2}$ & ternary & $3.0 \pm 0.1$ & 26 \\
$\mathrm{Cd}^{+2}$ & ternary & $0.8 \pm 0.04$ & 4 \\
$\mathrm{Ni}^{+2}$ & ternary & $0.6 \pm 0.03$ & 4 \\
\hline
\end{tabular}

The different overall metal retentions in multimetal solution (batch and column tests) may be ascribed to steric hindrance of the hydrated metal ions at the sorbent silicate functional groups, provided that the free migration is possible as the openings in the silicate lattice are sufficiently large [24]. In the present case, as pore radii are larger than metal hydrated radii, the different overall metal retentions may be ascribed to the relative free energies of hydration/dehydration of the exchanging species (ions and functional groups) (Equation (3)).

From Table 4, it is clearly evidenced that lead ions, with the lowest energy and hydrated radius, show the best interaction with the perlite functional groups [25] and, consequently, the best retention capacities. For this reason, lead ions engage functional groups more quantitatively than cadmium, showing larger hydrated radius and higher free energy of hydration. Moreover, nickel ions, with the highest free energy of hydration, show a definitely more difficult dehydration of ions and consequently the lowest figures.

Table 4. Relevant ionic properties functional to retention phenomena.

\begin{tabular}{ccc}
\hline Metal & Hydrated Radius (̊̊) & Free Energy of Hydration (Kcal/g-ion) \\
\hline $\mathrm{Pb}^{+2}$ & 4.01 & -357.8 \\
$\mathrm{Cd}^{+2}$ & 4.26 & -430.5 \\
$\mathrm{Ni}^{+2}$ & 4.04 & -494.2 \\
\hline
\end{tabular}

The final destination of metal-laden perlite was cement conglomerates formulation. Specifically, a quantitative substitution of the conventional (sand) aggregate was carried out. The reference material (mortar), characterized by exhausted silica, was submitted to a jar test to evaluate potential release of lead ions [16]. Data from the leaching test summarize that the release of lead ions $\left(2 \mu \mathrm{g} / \mathrm{dm}^{3}\right)$ to the liquid-phase was below the maximum allowable concentrations enforced for hazardous waste disposal in controlled landfills $\left(10 \mu \mathrm{g} / \mathrm{dm}^{3}\right)$.

Thermal conductivity, $\lambda$, of the lightweight specimens was determined [17]. Specifically, the reference materials showed lower thermal conductivities with respect to the conventional (sand containing) mortars which were assumed as the control [26,27]. Reduction of average $\lambda$ figures ( 0.39 vs. $2.06 \mathrm{~W} / \mathrm{mK}$ ) was attributed to the peculiar thermal insulating properties of the perlite after the open and closed porosity present on the material limiting heat transport in the silica lattice (Figure 1). Normalized resistance to compression, $R c$, of lightweight mortars (28 days aging) exceeded 16.4 $\mathrm{N} / \mathrm{mm}^{2}$ as compared to conventional control figures in the range of $47.2 \mathrm{~N} / \mathrm{mm}^{2}$, still in the accepted conformity range for plasters and masonries.

It is worth recalling that the aim of the present paper was to employ in wastewater treatments an aggregate typically used in the construction industry. The experimental retentions obtained for lead ion removal were not comparable with those reported in literature (zeolites, ion exchange resins) [28-31], but the novelty of this approach was to re-use lead ion-laden perlite as lightweight material for the preparation of environmentally-safe and thermal insulating cement conglomerates. This is also remarkable considering that an hazardous waste can be embedded in a cement matrix and re-used in the construction industry instead of being sent to landfill [32,33]. 


\section{Conclusions}

The sorption properties of a porous alumosilicate aggregate, namely perlite, toward lead ions was shown through batch equilibrium and column (dynamic) tests in single and multimetal solutions.

It was supposed that the dominant retention mechanism of lead ions at the negatively charged silicate functional groups, present on the perlite material, was ion exchange together with Van der Waals interactions.

As for environmental applications, metal-laden perlite may be used in the construction industry to replace conventional aggregates without any major limitation.

Acknowledgments: The authors wish to thank Pietro Stefanizzi for thermal measurements and Adriano Boghetich for mechanical tests. Regione Puglia is gratefully acknowledged for financial support (X-ray Lab Project-Reti di Laboratori Pubblici di Ricerca, codice progetto 45 and 56).

Author Contributions: Andrea Petrella: batch and column tests, discussion of the results. Pinalysa Cosma: batch and column tests, discussion of the results. Vito Rizzi: sample preparation and SEM characterizations together with tests on the metal laden cement composites. Nicoletta De Vietro: porosity measurements.

Conflicts of Interest: The authors declare no conflict of interest.

\section{References}

1. Harben, P.W.; Bates, R.L. Industrial Minerals Geology and World Deposits; Metal Bulletin Inc.: London, UK, 1990; p. 312.

2. Femina Carolin, C.; Senthil Kumar, P.; Saravanan, A.; Janet Joshiba, G.; Naushad, Mu. Efficient techniques for the removal of toxic heavy metals from aquatic environment: A Review. J. Environ. Chem. Eng. 2017, 5, 2782-2799. [CrossRef]

3. Wang, X.; Tian, Y.; Zhao, X. The influence of dual-substrate-layer extensive green roofs on rainwater runoff quantity and quality. Sci. Total Environ. 2017, 592, 465-476. [CrossRef] [PubMed]

4. Sari, A.; Tuzen, M.; Citak, D.; Soylak, M.J. Adsorption characteristics of $\mathrm{Cu}(\mathrm{II})$ and $\mathrm{Pb}(\mathrm{II})$ onto expanded perlite from aqueous solution. J. Hazard. Mater. 2007, 148, 387-394. [CrossRef] [PubMed]

5. Gupta, V.K. Equilibrium uptake, sorption dynamics, process development, and column operations for the removal of copper and nickel from aqueous solution and wastewater using activated slag, a low cost adsorbent. Ind. Eng. Chem. Res. 1998, 37, 192-202. [CrossRef]

6. Kenawy, I.M.M.; Hafez, M.A.H.; Akl, M.A.; Lashein, R.R. Determination by AAS of some trace heavy metal ions in some natural and biological samples after their preconcentration using newly chemically modified chloromethylated polystyrene-PAN ion-exchanger. Anal. Sci. 2000, 16, 493-500. [CrossRef]

7. Leinonen, H.; Lehto, J. Ion exchange of nickel by iminodiacetic acid chelating resin Chelex 100. React. Funct. Polym. 2000, 43, 1-6. [CrossRef]

8. Lin, S.H.; Lai, S.L.; Leu, H.G. Removal of heavy metals from aqueous solution by chelating resin in a multistage adsorption process. J. Hazard. Mater. 2000, 76, 139-153. [CrossRef]

9. Pehlivan, E.; Altun, T. The study of various parameters affecting the ion exchange of $\mathrm{Cu}^{2+}, \mathrm{Zn}^{2+}, \mathrm{Ni}^{2+}$, $\mathrm{Cd}^{2+}$, and $\mathrm{Pb}^{2+}$ from aqueous solution on Dowex 50W synthetic resin. J. Hazard. Mater. 2006, 134, 149-156. [CrossRef] [PubMed]

10. Freundlich, H.M.F. Uber die adsorption in losungen. Z. Phys. Chem. 1906, 57, 385-470. [CrossRef]

11. Langmuir, I. The adsorption of gases on plane surface of glass, mica and platinum. J. Am. Chem. Soc. 1918, 40, 1361-1403. [CrossRef]

12. Petrella, A.; Petruzzelli, V.; Ranieri, E.; Catalucci, V.; Petruzzelli, D. Sorption of Pb(II), Cd(II) and Ni(II) from single- and multimetal solutions by recycled waste porous glass. Chem. Eng. Commun. 2016, 203, 940-947. [CrossRef]

13. Petrella, A.; Petrella, M.; Boghetich, G.; Basile, T.; Petruzzelli, V.; Petruzzelli, D. Heavy metals retention on recycled waste glass from solid wastes sorting operations: A comparative study among different metal species. Ind. Eng. Chem. Res. 2012, 51, 119-125. [CrossRef]

14. Petrella, A.; Petruzzelli, V.; Basile, T.; Petrella, M.; Boghetich, G.; Petruzzelli, D. Recycled porous glass from municipal/industrial solid wastes sorting operations as a lead ion sorbent from wastewaters. React. Funct. Polym. 2010, 70, 203-209. [CrossRef] 
15. Cement Composition, Specifications and Conformity Criteria for Common Cements. Available online: http:/ / store.uni.com/magento-1.4.0.1/index.php/en-197-1-2011.html (accessed on 14 September 2011).

16. Characterization of Waste-Compliance Test for Leaching of Granular Waste Materials and Sludges. Available online: http://store.uni.com/magento-1.4.0.1/index.php/en-12457-2-2002.html (accessed on 18 September 2002).

17. Mills, A.F. Basic Heat and Mass Transfer; Prentice Hall: Upper Saddler River, NJ, USA, 1999; Volume 2, pp. 745-833.

18. Methods of Testing Cement-Part 1: Determination of Strength. Available online: http://store.uni.com/ magento-1.4.0.1/index.php/en-196-1-2016.html (accessed on 27 April 2016).

19. Helfferich, F. Ion Exchange; McGraw Hill: New York, NY, USA, 1962.

20. Dakiky, M.; Khamis, M.; Manassra, A.; Mer'eb, M. Selective adsorption of chromium(VI) in industrial wastewater using low-cost abundantly available adsorbents. Adv. Environ. Res. 2002, 6, 533-540. [CrossRef]

21. Pradhan, J.; Das, S.N.; Thakur, R.S. Adsorption of hexavalent chromium from aqueous solution by using activated red mud. J. Colloid Interface Sci. 1999, 217, 137-141. [CrossRef] [PubMed]

22. Rengaraj, S.; Kyeong-Ho, Y.; Seung-Hyeon, M. Removal of chromium from water and wastewater by ion exchange resins. J. Hazard. Mater. B 2001, 87, 273-287. [CrossRef]

23. Saeed, A.; Iqbal, M.; Akhtar, M.W. Removal and recovery of lead(II) from single and multimetal (Cd, Cu, $\mathrm{Ni}, \mathrm{Zn}$ ) solutions by crop milling waste (black gram husk). J. Hazard. Mater. 2005, 117, 65-73. [CrossRef] [PubMed]

24. Manliu, E.; Loizidou, M.; Spyrellis, N. Uptake of lead and cadmium by clinoptilolite. Sci. Total Environ. 1994, 149, 139-144. [CrossRef]

25. Robinson, R.A.; Stokes, R.H. Electrolyte Solutions; Courier Dover Publications: Mineola, NY, USA, 1970.

26. Petrella, A.; Petrella, M.; Boghetich, G.; Petruzzelli, D.; Ayr, U.; Stefanizzi, P.; Calabrese, D.; Pace, L. Thermo-acoustic properties of cement-waste-glass mortars. Proc. Inst. Civ. Eng. Constr. Mater. 2009, 162, 67-72. [CrossRef]

27. Petrella, A.; Petrella, M.; Boghetich, G.; Petruzzelli, D.; Calabrese, D.; Stefanizzi, P.; De Napoli, D.; Guastamacchia, M. Recycled waste glass as aggregate for lightweight concrete. Proc. Inst. Civ. Eng. Constr. Mater. 2007, 160, 165-170. [CrossRef]

28. Vergili, I.; Soltobaeva, G.; Kaya, Y.; Beril, G.Z.; Çavus, S.; Gürdağ, G. Study of the Removal of Pb(II) Using a Weak Acidic Cation Resin: Kinetics, Thermodynamics, Equilibrium, and Breakthrough Curves. Ind. Eng. Chem. Res. 2013, 52, 9227-9238. [CrossRef]

29. Wang, Z.Z.; Duan, H.D.; Meng, X.; Zhang, Y.F.; Qi, H.M. Adsorption of lead(II) from aqueous solution by two modified porous chelating resins based on (3-mercaptopropyl) trimethoxysilane. Macromol. Res. 2016, 24, 757-766. [CrossRef]

30. Chen, G.; Shah, K.J.; Shi, L.; Chiang, P.C. Removal of $\mathrm{Cd}(\mathrm{II})$ and $\mathrm{Pb}(\mathrm{II})$ ions from aqueous solutions by synthetic mineral adsorbent: Performance and mechanisms. Appl. Surf. Sci. 2017, 409, 296-305. [CrossRef]

31. Salem, S.; Salem, A. A novel design for clean and economical manufacturing new nano-porous zeolite based adsorbent by alkali cement kiln dust for lead uptake from wastewater. J. Clean. Prod. 2017, 143, 440-451. [CrossRef]

32. Specification for Mortar for Masonry-Part 1: Rendering and Plastering Mortars. Available online: http: / / store.uni.com/magento-1.4.0.1/index.php/en-998-1-2016.html (accessed on 09 November 2016).

33. Specification for Mortar for Masonry. Masonry Mortars. Available online: http://store.uni.com/magento-1. 4.0.1/index.php/en-998-2-2016.html (accessed on 09 November 2016).

(C) 2017 by the authors. Licensee MDPI, Basel, Switzerland. This article is an open access article distributed under the terms and conditions of the Creative Commons Attribution (CC BY) license (http://creativecommons.org/licenses/by/4.0/). 